\title{
ANALISIS PERWILAYAHAN DAN KONTRIBUSI KOMODITAS JERUK SIAM TERHADAP PEREKONOMIAN KABUPATEN BANYUWANGI
}

\author{
Rizqa Nurmalia*, Soetriono, Anik Suwandari \\ Program Studi Agribisnis, Fakultas Pertanian, Universitas Jember, \\ Jl. Kalimantan No. 37 Kampus Tegalboto Sumbersari Jember \\ *Corresponding author: nurmaliarizqa@ gmail.com
}

\begin{abstract}
Siam Oranges in Banyuwangi is spread in nine central districts. The aim of the study is to explain the districts that are the basis of Siam Oranges, the characteristics of the spread of Siam Oranges, and it contribution to the economy of Banyuwangi. The method used in this study is an analytical method. The data used in the study were secondary data from the Department of Agriculture, Forestry, and Plantation of Banyuwangi. Analysis of data with the $L Q$ method, localization and specialization, and contributions will be done through the proportion formula. $L Q$ analysis is calculated using three indicators, namely land area, production and revenue. The results of the analysis show that the based on the average $L Q$ value from 2013-2017 which has consistently been the base district of the Siam Oranges based on three different indicators are Bangorejo District, Purwoharjo District, Tegaldlimo District, Cluring District, and Gambiran District. Localization analysis shows that Siam Oranges are not localized in a particular district. Specialization analysis shows that in none of the sub-districts of the Siam Oranges base specialize in just the Siam Oranges commodity. Contribution analysis shows that the contribution of Siam Oranges to the economy of Banyuwangi from 2013-2017 is 0,0019; 0,0041; 0,0102; 0,0050 dan 0,0020. It means low because these presentage is less than the average contribution component of economy Banyuwangi.
\end{abstract}

Keywords: siam oranges, base districts, localization, specialization, contribution.

\begin{abstract}
Abstrak: Jeruk Siam di Kabupaten Banyuwangi tersebar di sembilan kecamatan sentra. Tujuan penelitian adalah untuk menjelaskan kecamatan basis Jeruk Siam, karakteristik penyebarannya, serta kontribusinya terhadap perekonomian Kabupaten Banyuwangi. Metode yang digunakan dalam penelitian adalah metode analitik. Data yang digunakan dalam penelitian adalah data sekunder yang berasal dari Dinas Pertanian, Kehutanan, dan Perkebunan Kabupaten Banyuwangi. Analisis data menggunakan metode LQ, lokalisasi dan spesialisasi, serta analisis kontribusi ekonomi melalui rumus proporsi. Analisis LQ dihitung dengan menggunakan tiga indikator yaitu luas lahan, produksi dan penerimaan. Hasil penelitian menunjukkan bahwa berdasarkan rata-rata nilai LQ tahun 2013-2017, yang secara konsisten menjadi kecamatan basis Jeruk Siam pada tiga indikator yang berbeda selama kurun waktu lima tahun yaitu Kecamatan Bangorejo, Kecamatan Purwoharjo, Kecamatan Tegaldlimo, Kecamatan Cluring, dan Kecamatan Gambiran. Analisis lokalisasi menunjukkan bahwa Jeruk Siam tidak terlokalisasi pada kecamatan tertentu melainkan terlokalisasi di kecamatan-kecamatan basis. Analisis spesialisasi menunjukkan bahwa Kabupaten Banyuwangi tidak menspesialisasikan kegiatan pertaniannya hanya pada komoditas Jeruk Siam saja. Analisis kontribusi menunjukkan bahwa prsentase kontribusi Jeruk Siam terhadap perekonomian Banyuwangi dari tahun 2013 sampai 2017 berturut-turut adalah 0,$0019 ; 0,0041 ; 0,0102 ; 0,0050$ dan 0,0020 yang berarti bahwa kontribusi Jeruk Siam terhadap perekonomian Kabupaten Banyuwangi adalah rendah karena angka presentase kontribusi Jeruk Siam lebih kecil dari rata-rata
\end{abstract}


kontribusi komponen penyusun PDRB perekonomian Kabupaten Banyuwangi $(0,015 \%)$.

Kata Kunci: jeruk siam, kecamatan basis, lokalisasi, spesialisasi, kontribusi.

\section{PENDAHULUAN}

Pusat Data dan Informasi Pertanian (2016) mencatat bahwa Jeruk Siam di Jawa Timur dihasilkan dari beberapa kabupaten sebagai sentra produksinya, diantaranya Kabupaten Banyuwangi, Jember, Malang, Pasuruan, Lumajang dan lainnya. Produksi Jeruk Siam tertinggi tahun 2015 sebesar 205.685 ton dihasilkan oleh Kabupaten Banyuwangi dengan nilai share terhadap provinsi sebesar $42,82 \%$. Hal tersebut dapat diartikan bahwa hampir sebagian besar kebutuhan Jeruk Siam Provinsi Jawa Timur adalah dipenuhi oleh Kabupaten Banyuwangi. Berikut gambaran perkembangan produksi Jeruk Siam di beberapa kecamatan penghasil Jeruk Siam di Kabupaten Banyuwangi.

Berdasarkan Tabel 1 terlihat bahwa produksi Jeruk Siam yang dihasilkan dari tiaptiap kecamatan dari tahun 2013-2017 adalah berbeda-beda. Tahun 2013 produksi Jeruk Siam tertinggi dihasilkan oleh Kecamatan Tegaldlimo sebesar 395.718,75 kw. Produksi Jeruk Siam tertinggi tahun 2014 dihasilkan oleh Kecamatan Bangorejo sebesar 2.457.890 kw. Tahun 2015 Kecamatan Bangorejo masih menjadi penghasil Jeruk Siam tertinggi yaitu sebesar 8.039.430,00 kw. Tahun 2016 produksi Jeruk Siam tertinggi juga masih dihasilkan oleh Kecamatan Bangorejo dengan produksi sebesar $1.800 .016 \mathrm{kw}$. Tahun 2017 produksi Jeruk Siam tertinggi kembali dihasilkan oleh Kecamatan Tegaldlimo. Pergantian Kecamatan yang menjadi daerah dengan produksi Jeruk Siam tertinggi serta beragamnya jumlah produksi yang dihasilkan oleh masing-masing kecamatan menunjukkan potensi yang berbeda pula yang dimiliki tiap daerah.

Berdasarkan Rencana Strategis Dinas Pertanian Kabupaten Banyuwangi Tahun 20162021, salah satu strategi pembangunan yang harus diperhatikan adalah strategi pengembangan kawasan strategis kabupaten melalui strategi pengembangan kawasan strategis ekonomi yang meliputi penetapan kawasan hortikultura. Mendukung strategi tersebut, produk hortikultura Kabupaten Banyuwangi yang terbagi menjadi dua produk yaitu sayuran dan buah-buahan dimana salah satu komoditas hortikultura buah unggulannya adalah Jeruk Siam yang tersebar di beberapa kecamatan dengan produksi berbeda-beda juga terlihat adanya gambaran pergantian kecamatan yang menempati posisi sebagai kecamatan dengan produksi Jeruk Siam tertinggi tiap tahunnya, maka melalui gambaran tersebut tentunya komoditas Jeruk Siam juga perlu menjadi salah satu fokus komoditas yang memerlukan penetapan kawasan strategisnya sehingga dapat teridentifikasi dengan jelas kecamatan mana yang memiliki keunggulan komparatif yang potensial untuk dilakukan pengembangan. Oleh karena itu, pemetaan wilayah untuk komoditas Jeruk Siam di Banyuwangi menjadi penting dilakukan. Adapun tujuan dari penelitian adalah untuk

Tabel 1. Perkembangan Produksi Jeruk Siam di Beberapa Kecamatan di Kabupaten Banyuwangi Tahun 2013-2017

\begin{tabular}{rlrrrrr}
\hline \multirow{2}{*}{ No. } & \multirow{2}{*}{ Kecamatan } & \multicolumn{5}{c}{ Produksi (kw) } \\
\cline { 3 - 6 } & & $\mathbf{2 0 1 3}$ & $\mathbf{2 0 1 4}$ & $\mathbf{2 0 1 5}$ & $\mathbf{2 0 1 6}$ & $\mathbf{2 0 1 7}$ \\
\hline 1. & Pesanggaran & $33.795,90$ & $50.785,00$ & $71.474,00$ & $60.239,00$ & $14.940,00$ \\
2. & Siliragung & $37.199,25$ & $69.230,00$ & $171.260,00$ & $412.984,00$ & $303.610,00$ \\
3. & Bangorejo & $381.037,50$ & $2.457 .890,00$ & $8.039 .430,00$ & $1.800 .016,00$ & $113.488,00$ \\
4. & Purwoharjo & $347.568,30$ & $290.565,00$ & $106.841,00$ & $449.654,00$ & $177.791,00$ \\
5. & Tegaldlimo & $395.718,75$ & $300.249,00$ & $371.304,00$ & $1.024 .242,00$ & $942.100,00$ \\
6. & Muncar & $62.295,75$ & $30.810,00$ & 0 & $191.280,00$ & $123.760,00$ \\
7. & Cluring & $61.524,45$ & $45.905,00$ & $22.037,00$ & $482.672,00$ & $691.746,00$ \\
8. & Gambiran & $50.597,33$ & $33.210,00$ & $29.125,00$ & $577.432,00$ & $171.521,00$ \\
9. & Tegalsari & $67.770,00$ & $31.865,00$ & 0 & $151.630,00$ & 67.456 .00 \\
\hline
\end{tabular}

Sumber: Dinas Pertanian Kehutanan dan Perkebunan Banyuwangi, 2018 (data diolah). 
menjelaskan kecamatan basis Jeruk Siam, karakteristik penyebaran Jeruk Siam serta kontribusi Jeruk Siam terhadap perekonomian Kabupaten Banyuwangi.

Berdasarkan hasil penelitian Mulyono dan Munibah (2016) yang menggunakan pendekatan Location Quotient dan Shift Share Analysis dalam penentuan komoditas unggulan di Kabupaten Bantul, diketahui bahwa Padi Sawah memiliki keunggulan komparatif di 12 kecamatan dengan nilai LQ terbesar yaitu 1,33, Jagung memiliki keunggulan komparatif di 4 kecamatan dengan nilai LQ terbesar yaitu 2,29, Kacang Tanah memiliki keunggulan komparatif di 6 kecamatan dengan nilai LQ terbesar yaitu 3,10, Ubi Jalar memiliki keunggulan komparatif di 3 kecamatan dengan nilai LQ terbesar yaitu 18,04, serta Ubi Kayu memiliki keunggulan komparatif di 3 kecamatan dengan nilai LQ terbesar yaitu 4,14. Komoditas-komoditas tersebut memiliki keunggulan komparatif di kecamatan tertentu karena share luas panennya di tingkat kecamatan lebih tinggi dibandingkan dengan tingkat kabupaten, sehingga nilai LQ lebih besar dari 1. Komoditas yang memiliki keunggulan komparatif menunjukkan komoditas tersebut diproduksi melalui dominasi dukungan sumber daya alam, dimana daerah lain tidak mampu memproduksinya.

Boekoesoe (2011) dengan menggunakan analisis LQ, menemukan bahwa terdapat 18 kecamatan yang menjadi basis wilayah komoditas mangga dimana luas lahan tanaman mangga yang terbesar adalah di Kecamatan Tilongkabila, Kabupaten Bone Bolango. Terdapat 19 komoditi buah-buahan di Provinsi Gorontalo. Berdasarkan analisis lokalisasi terdapat 3 komoditi buah-buahan yang nilai koefisien lokalisasinya lebih besar dari satu $(\alpha>1)$, yaitu jeruk besar $(\alpha=1,491)$, rambutan $(\alpha=1,327)$, dan salak $(\alpha=1,258)$. Sedangkan komoditi yang paling kecil nilai koefisien lokalisasinya adalah pisang $(\alpha=0,175)$, yang berarti bahwa komoditi pisang adalah paling menyebar di wilayah-wilayah kecamatan di Provinsi Gorontalo atau dengan kata lain hampir seluruh kecamatan terdapat pisang. Berdasarkan analisis koefisien spesialisasi terdapat 6 komoditi buah yang menjadi spesial bagi Provinsi Gorontalo dengan nilai $\beta>1$ yaitu mangga $(\beta=4,178)$, nangka $(\beta=2,912)$, pisang $(\beta=2,907)$, pepaya $(\beta=1,940)$, jeruk siam $(\beta=1,677)$, dan nanas $(\beta=1,440)$. Artinya keenam komoditi buah tersebut dapat dijadikan andalan hortikultura buah-buahan Provinsi Gorontalo yang dapat dikembangkan mulai dari agribisnis hulu sampai hilir karena memiliki keunggulan komparatif.

Larasati (2011) melakukan penelitian untuk mengetahui kontribusi ubi jalar terhadap PDRB Provinsi Jawa Timur menggunakan analisis proporsi dengan kriteria yang digunakan adalah kontribusi ubi jalar dikatakan tinggi jika presentasenya lebih dari 0,093\% dan dikatakan rendah jika presentasenya kurang dari $0,093 \%$. Berdasarkan hasil penelitian, diketahui bahwa pada tahun 1994 kontribusi ubi jalar sebesar 0,0025\% dan mengalami peningkatan pada tahun 1995 menjadi 0,0030\%. Kontribusi ubi jalar pada tahun 1996 dan 1997 adalah $0,002 \%$ dan terjadi peningkatan pada tahun 1998 yaitu 0,005\%. Pada tahun 1999 kontribusinya mengalami penurunan yaitu sebesar $0,001 \%$ dan semakin menurun pada tahun 2000 sampai dengan 2009 menjadi dibawah $0,001 \%$. Hal tersebut menunjukkan bahwa kontribusi ubi jalar terhadap PDRB Provinsi Jawa Timur dari tahun 1994-2009 cenderung mengalami penurunan dan secara keseluruhan kontribusinya dikatakan rendah karena kurang dari 0,093\%.

Penelitian analisis perwilayahan dan kontribusi Jeruk Siam di Banyuwangi penting dilakukan melihat kondisi tersebarnya Jeruk Siam di beberapa wilayah sentra dengan produksi yang berbeda-beda. Gambaran tersebut menunjukkan bahwa potensi yang dimiliki tiap wilayahpun berbeda. Wilayah basis Jeruk Siam adalah wilayah yang memiliki keunggulan komparatif dibandingkan wilayah non basis Jeruk Siam sehingga wilayah basis merupakan wilayah yang paling potensial untuk dilakukan pengembangan. Kebaruan dari penelitian ini adalah apabila penelitianpenelitian sebelumnya hanya melibatkan 1 indikator saja dalam menentukan wilayah basis namun pada penelitian ini dilakukan perhitungan LQ dengan menggunakan 3 indikator. Hal tersebut dapat menunjukkan wilayah yang mana yang secara konsisten menjadi wilayah basis Jeruk Siam dengan tiga indikator berbeda sehingga wilayah basis Jeruk Siam yang dihasilkan dalam penelitian terbukti benar-benar unggul tidak hanya dalam satu atau dua indikator namun unggul dalam tiga 
indikator. Analisis kontribusi dilakukan untuk menjelaskan Jeruk Siam sebagai salah satu komoditas buah unggulan yang produksinya tinggi di Kabupaten Banyuwangi apakah dapat memberikan kontribusi yang tinggi pula terhadap perekonomian Banyuwangi.

\section{METODE PENELITIAN}

Penelitian dilakukan di Kabupaten Banyuwangi Provinsi Jawa Timur. Metode yang digunakan dalam penentuan daerah penelitian adalah metode secara sengaja (purposive methode). Pemilihan daerah penelitian didasarkan atas pertimbangan bahwa Kabupaten Banyuwangi merupakan wilayah dengan tingkat kontribusi tertinggi Jeruk Siam di Provinsi Jawa Timur, Metode yang digunakan dalam penelitian ini adalah metode analitik. Menurut Nazir (2005), metode analitik bertujuan untuk menguji hipotesis-hipotesis dan melakukan interpretasi yang lebih mendalam tentang hubunganhubungan. Data yang digunakan dalam penelitian adalah data sekunder. Sumber data utama dalam penelitian berasal dari Dinas Pertanian, Kehutanan, dan Perkebunan Kabupaten Banyuwangi, Badan Pusat Statistik (BPS) Kabupaten Banyuwangi, serta instansi terkait lainnya. Adapun data yang diperlukan dalam penelitian adalah data luas lahan, produksi, dan harga buah-buahan setiap kecamatan di Kabupaten Banyuwangi tahun 2013 sampai dengan 2017 serta data PDRB Kabupaten Banyuwangi atas dasar harga berlaku tahun 2013-2017.

Analisis data yang digunakan untuk mencapai tujuan pertama menggunakan analisis LQ (Location Quotient) oleh Soetriono (1996) dan Suharyanto et al. (2013) dengan rumus:

$\mathrm{LQ}=\left(\mathrm{v}_{\mathrm{i}} / \mathrm{v}_{\mathrm{t}}\right) /\left(\mathrm{Vi} / \mathrm{V}_{\mathrm{t}}\right)$

Keterangan:

$\mathrm{LQ}=$ Nilai $\mathrm{LQ}$ rasio komoditas Jeruk Siam di setiap kecamatan di Kabupaten Banyuwangi

$\mathrm{v}_{\mathrm{i}}=$ Luas lahan, produksi, penerimaan komoditas Jeruk Siam periode tahun 2013-2017 di Kecamatan $i$

$\mathrm{v}_{\mathrm{t}}=$ Total Luas lahan, produksi, penerimaan seluruh komoditas buah periode tahun 2013-2017 di Kecamatan $i$

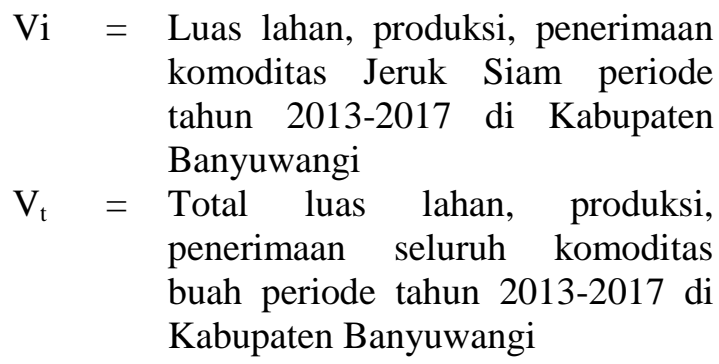

Kriteria pengambilan keputusan:

1. Apabila LQ $>1$, artinya kecamatan i merupakan basis Jeruk Siam berdasarkan indikator luas lahan, produksi, penerimaan.

2. Apabila $\mathrm{LQ}<1$, artinya kecamatan i bukan merupakan basis Jeruk Siam berdasarkan indikator luas lahan, produksi, penerimaan.

Analisis data yang digunakan untuk mencapai tujuan kedua menggunakan analisis lokalisasi dan spesialisasi. Menurut Pasaribu dan Soetriono (2009) menyatakan bahwa penggunaan analisis lokalisasi dan spesialisasi dapat digunakan rumus:

Rumus Lokalisasi: $\alpha_{\mathrm{i}}=\left[\mathrm{S}_{\mathrm{i}} / \mathrm{N}_{\mathrm{i}}\right]-\left[\sum \mathrm{S}_{\mathrm{i}} / \sum \mathrm{N}_{\mathrm{i}}\right] \ldots(2)$

Keterangan:

$$
\begin{aligned}
& \alpha_{\mathrm{i}}= \begin{array}{l}
\text { Koefisien lokalisasi komoditas } \\
\text { Jeruk Siam }
\end{array} \\
& \mathrm{S}_{\mathrm{i}}= \begin{array}{l}
\text { Luas lahan, produksi, penerimaan } \\
\text { komoditas Jeruk Siam periode } \\
\text { tahun 2013-2017 di Kecamatan } i
\end{array} \\
& \mathrm{~N}_{\mathrm{i}}= \begin{array}{l}
\text { Luas lahan, produksi, penerimaan } \\
\text { komoditas Jeruk Siam periode } \\
\text { tahun 2013-2017 di Kabupaten }
\end{array} \\
& \text { Banyuwangi } \\
& \Sigma \mathrm{S}_{\mathrm{i}}= \begin{array}{l}
\text { Total luas lahan, produksi, } \\
\text { penerimaan seluruh komoditas } \\
\text { buah periode tahun 2013-2017 di }
\end{array} \\
& \text { Kecamatan } i \\
& \text { Total luas lahan, produksi, } \\
& \text { penerimaan seluruh komoditas } \\
& \text { buah periode tahun 2013-2017 di } \\
& \text { Kabupaten Banyuwangi }
\end{aligned}
$$

Kriteria pengambilan keputusan:

1. Apabila $\alpha \geq 1$, artinya komoditas Jeruk Siam terlokalisasi pada suatu kecamatan tertentu.

2. Apabila $\alpha<1$, artinya komoditas Jeruk Siam tidak terlokalisasi pada suatu kecamatan tertentu atau dengan kata lain menyebar dibeberapa kecamatan di Kabupaten Banyuwangi. 
Rumus Spesialisasi:

$\beta_{i}=\left[\mathrm{S}_{\mathrm{i}} / \sum \mathrm{S}_{\mathrm{i}}\right]-\left[\mathrm{N}_{\mathrm{i}} / \sum \mathrm{N}_{\mathrm{i}}\right]$

Keterangan:

$\beta_{\mathrm{i}}=$ Koefisien spesialisasi komoditas Jeruk Siam

$\mathrm{S}_{\mathrm{i}} \quad=$ Luas lahan, produksi, penerimaan komoditas Jeruk Siam periode tahun 2013-2017 di Kecamatan $i$

$\mathrm{N}_{\mathrm{i}} \quad=$ Luas lahan, produksi, penerimaan komoditas Jeruk Siam periode tahun 2013-2017 di Kabupaten Banyuwangi

$\sum \mathrm{S}_{\mathrm{i}}=$ Total luas lahan, produksi, penerimaan seluruh komoditas buah periode tahun 2013-2017 di Kecamatan $i$

$\sum \mathrm{N}_{\mathrm{i}}=$ Total luas lahan, produksi, penerimaan seluruh komoditas buah periode tahun 2013-2017 di Kabupaten Banyuwangi

Kriteria pengambilan keputusan:

1. Apabila $\beta^{\geq}$, artinya suatu wilayah (kecamatan) sudah menspesialisasikan pada satu jenis komoditas pertanian tertentu dalam hal ini komoditas Jeruk Siam.

2. Apabila $\beta<1$, artinya suatu wilayah (kecamatan) belum dan atau tidak menspesialisasikan pada satu jenis komoditas pertanian tertentu dalam hal ini komoditas Jeruk Siam.

Analisis data yang digunakan untuk mencapai tujuan ketiga menggunakan rumus proporsi oleh Djarwanto (2001) sebagai berikut:

Kontribusi $(\%)=[\mathrm{X} / \mathrm{Y}] \times 100 \%$

Keterangan:

$\mathrm{X}=$ PDRB komoditas Jeruk Siam Kabupaten

Banyuwangi (Rp)

$\mathrm{Y}=$ PDRB sektor pertanian di Kabupaten Banyuwangi ( $\mathrm{Rp}$ )

Kriteria pengambilan keputusan:

1. Apabila kontribusi $(\%)>$ rata-rata kontribusi PDRB Kabupaten Banyuwangi, maka kontribusi Jeruk Siam terhadap PDRB Kabupaten Banyuwangi adalah tinggi
2. Apabila kontribusi $(\%) \leq$ rata-rata kontribusi PDRB Kabupaten Banyuwangi, maka kontribusi Jeruk Siam terhadap PDRB Kabupaten Banyuwangi adalah rendah

Rata-rata kontribusi PDRB Kabupaten Banyuwangi $=$

$\left[1 / \sum\right.$ komponen penyusun PDRB Kabupaten

Banyuwangi $] \times 100 \%=[1 / 21] \times 100 \%=$ $4,76 \%$

$\sum$ komponen penyusun PDRB Kabupaten Banyuwangi $=$ sektor pertanian, kehutanan, dan perikanan; sektor pertambangan dan penggalian; sektor industri pengolahan; sektor pengadaan listrik dan gas; sektor pengadaan air, pengelolaan sampah, limbah, dan daur ulang; sektor konstruksi; sektor perdagangan besar dan eceran, reparasi mobil dan sepeda motor; sektor transportasi dan pergudangan; sektor penyediaan akomodasi dan makan minum; sektor informasi dan komunikasi; sektor jasa keuangan dan asuransi; sektor real estate; sektor jasa perusahaan; sektor administrasi pemerintahan, pertahanan dan jaminan sosial wajib; sektor jasa pendidikan; sektor jasa kesehatan dan kegiatan sosial; serta sektor jasa lainnya.

Nilai rata-rata kontribusi diatas masih dibagi lagi dengan komponen penyusun sektor pertanian yang terdiri dari 7 subsektor, sehingga perhitungannya menjadi:

Rata-rata kontribusi komponen penyusun Sektor pertanian $=4,76 \% / 7=0,68 \%$

Nilai rata-rata kontribusi diatas masih harus dibagi lagi dengan total komoditas penyusun subsektor hortikultura yang terdiri dari 48 komoditas, sehingga perhitungannya menjadi:

Rata-rata kontribusi komponen penyusun PDRB total Kabupaten Banyuwangi = $0,68 \% / 48=0,015 \%$

Berdasarkan perhitungan tersebut, kriteria yang digunakan dalam menentukan tinggi rendahnya kontribusi Jeruk Siam terhadap PDRB Kabupaten Banyuwangi adalah sebagai berikut: 
1. Apabila kontribusi (\%) $>0,015 \%$, maka kontribusi komoditas Jeruk Siam terhadap PDRB Kabupaten Banyuwangi adalah tinggi.

2. Apabila kontribusi $(\%) \leq 0,015 \%$, maka kontribusi komoditas Jeruk Siam terhadap PDRB Kabupaten Banyuwangi adalah rendah.

\section{HASIL DAN PEMBAHASAN}

Kecamatan Basis dan Non Basis Komoditas Jeruk Siam di Kabupaten Banyuwangi

Berdasarkan analisis LQ indikator luas lahan yang telah dilakukan, diperoleh nilai LQ Jeruk Siam seperti yang tersaji pada Tabel 2 .

Tabel 2. menunjukkan bahwa kecamatan yang menjadi basis Jeruk Siam dari tahun 2013-2017 berubah-ubah. Hal tersebut disebabkan oleh luas lahan yang juga berbedabeda setiap tahunnya di masing-masing kecamatan penghasil Jeruk Siam. Berdasarkan rata-rata nilai LQ terdapat sembilan (9) kecamatan yang merupakan wilayah basis Jeruk Siam. Kesembilan kecamatan tersebut adalah Kecamatan Pesanggaran, Siliragung, Bangorejo, Purwoharjo, Tegaldlimo, Muncar, Cluring, Gambiran, dan Kecamatan Tegalsari. Artinya bahwa komoditas Jeruk Siam di Kabupaten Banyuwangi memiliki keunggulan komparatif di sembilan kecamatan tersebut.

Berdasarkan konsistensinya, yang secara konsisten menempati posisi sebagai kecamatan basis pada tahun 2013-2017 berdasarkan indikator luas lahan adalah Kecamatan Siliragung, Purwoharjo, Cluring, Gambiran, dan Tegalsari.
Kecamatan Tegaldlimo, Kecamatan Bangorejo, Kecamatan Muncar dan Kecamatan Pesanggaran tidak menjadi kecamatan konsisten karena selama kurun waktu 20132017 terdapat satu tahun tertentu pada kecamatan-kecamatan tersebut yang menghasilkan nilai LQ kurang dari 1 atau tidak menjadi kecamatan basis Jeruk Siam. Hasil terebut secara berturut-turut yaitu Kecamatan Tegaldlimo menjadi kecamatan non basis Jeruk Siam pada tahun 2014, Kecamatan Bangorejo menjadi kecamatan non basis Jeruk Siam pada tahun 2017, Kecamatan Muncar menjadi kecamatan non basis Jeruk Siam pada tahun 2014 dan 2015, Kecamatan Pesanggaran menjadi kecamatan non basis Jeruk Siam pada tahun 2015. Kecamatan-kecamatan tersebut disebut non basis karena jumlah luas lahan Jeruk Siam yang dimiliki tidak mampu mengimbangi total luas lahan seluruh komoditas buah yang diusahakan masyarakat pada kecamatan-kecamatan tersebut yang juga berarti bahwa ada komoditas buah lain yang lebih mendominasi diusahakan masyarakat pada kecamatan-kecamatan tersebut.

Berdasarkan analisis LQ indikator produksi yang telah dilakukan, diperoleh hasil analisis seperti yang tersaji pada Tabel 3. Hasil analisis LQ berdasarkan indikator produksi menunjukkan bahwa terdapat lima (5) kecamatan yang menghasilkan nilai rata-rata LQ > 1 atau disebut sebagai kecamatan basis Jeruk Siam. Kelima kecamatan tersebut adalah Kecamatan Bangorejo, Purwoharjo, Tegaldlimo, Cluring, dan Kecamatan Gambiran. Berdasarkan konsistensinya per tahun, yang secara konsisten menempati posisi sebagai kecamatan basis komoditas Jeruk Siam

Tabel 2. Hasil analisis LQ Jeruk Siam Berdasarkan Indikator Luas Lahan (ha) di Kabupaten Banyuwangi

\begin{tabular}{llllrrrr}
\hline \multirow{2}{*}{ No } & \multirow{2}{*}{ Kecamatan } & \multicolumn{5}{c}{ Nilai LQ Indikator Luas Lahan } \\
\cline { 3 - 7 } & & 2013 & 2014 & 2015 & 2016 & 2017 & Rata-rata \\
\hline 1 & Pesanggaran & $\mathbf{1 , 8 5 0 8}$ & $\mathbf{1 , 6 4 0 9}$ & 0,5458 & $\mathbf{1 , 1 2 2 9}$ & $\mathbf{1 , 2 4 4 8}$ & $\mathbf{1 , 2 8 1 1}$ \\
2 & Siliragung & $\mathbf{1 , 6 7 4 1}$ & $\mathbf{2 , 2 1 8 9}$ & $\mathbf{1 , 2 7 3 7}$ & $\mathbf{1 , 3 7 5 9}$ & $\mathbf{1 , 5 2 8 9}$ & $\mathbf{1 , 6 1 4 3}$ \\
3 & Bangorejo & $\mathbf{1 , 6 2 0 0}$ & $\mathbf{3 , 1 7 6 3}$ & $\mathbf{2 , 4 4 5 3}$ & $\mathbf{1 , 7 9 6 0}$ & 0,0058 & $\mathbf{1 , 8 0 8 7}$ \\
4 & Purwoharjo & $\mathbf{4 , 0 0 6 7}$ & $\mathbf{4 , 0 5 6 4}$ & $\mathbf{2 , 7 4 4 9}$ & $\mathbf{2 , 0 9 5 1}$ & $\mathbf{2 , 2 8 5 0}$ & $\mathbf{3 , 0 3 7 6}$ \\
5 & Tegaldlimo & $\mathbf{2 , 1 3 1 6}$ & 0,7320 & $\mathbf{2 , 5 6 3 8}$ & $\mathbf{2 , 0 9 9 9}$ & $\mathbf{2 , 5 9 9 9}$ & $\mathbf{2 , 0 2 5 4}$ \\
6 & Muncar & $\mathbf{2 , 1 5 9 1}$ & 0,4577 & 0,6715 & $\mathbf{1 , 4 9 3 8}$ & $\mathbf{1 , 6 7 9 2}$ & $\mathbf{1 , 2 9 2 2}$ \\
7 & Cluring & $\mathbf{3 , 8 2 2 8}$ & $\mathbf{1 , 4 3 5 6}$ & $\mathbf{2 , 1 6 0 9}$ & $\mathbf{1 , 9 6 7 1}$ & $\mathbf{2 , 2 0 0 0}$ & $\mathbf{2 , 3 1 7 3}$ \\
8 & Gambiran & $\mathbf{1 , 6 7 8 6}$ & $\mathbf{1 , 0 2 7 1}$ & $\mathbf{2 , 0 7 9 5}$ & $\mathbf{1 , 6 9 6 7}$ & $\mathbf{1 , 9 2 5 6}$ & $\mathbf{1 , 6 8 1 5}$ \\
9 & Tegalsari & $\mathbf{3 , 9 2 8 0}$ & $\mathbf{1 , 4 0 8 9}$ & $\mathbf{1 , 3 0 8 7}$ & $\mathbf{1 , 4 8 5 6}$ & $\mathbf{1 , 6 4 6 3}$ & $\mathbf{1 , 9 5 5 5}$ \\
\hline
\end{tabular}

Sumber: Data Sekunder Diolah (2018) 
berdasarkan indikator produksi adalah tidak terdapat kecamatan yang selalu menghasilkan nilai LQ lebih dari satu (LQ>1) atau selalu menjadi kecamatan basis Jeruk Siam selama kurun waktu lima tahun tersebut. Kecamatan Purwoharjo dengan rata-rata LQ tertinggi pertama sebesar 1,75 tidak menjadi kecamatan konsisten karena pada tahun 2017 menghasilkan nilai LQ kurang dari $1(\mathrm{LQ}<1)$ atau tidak menjadi kecamatan basis Jeruk Siam. Kecamatan Tegaldlimo dengan rata-rata LQ tertinggi kedua sebesar 1,71 tidak menjadi kecamatan konsisten karena pada tahun 2015 dan 2017 menjadi kecamatan non basis Jeruk Siam. Kecamatan Bangorejo dengan rata-rata LQ tertinggi ketiga sebesar 1,70 tidak menjadi kecamatan konsisten karena pada tahun 2017 menjadi kecamatan non basis Jeruk Siam. Kecamatan Cluring dengan rata-rata LQ tertinggi keempat sebesar 1,40 juga tidak menjadi kecamatan konsisten karena pada tahun 2014 dan 2015 menjadi kecamatan non basis Jeruk Siam. Kecamatan Gambiran dengan rata-rata LQ tertinggi kelima atau rata-rata LQ terendah sebesar 1,39 tidak menjadi kecamatan konsisten karena pada tahun 2014 menjadi kecamatan non basis Jeruk Siam. Kecamatankecamatan tersebut menjadi kecamatan non basis Jeruk Siam karena jumlah produksi Jeruk Siam yang dihasilkan pada tahun-tahun tersebut tidak mampu mengimbangi total produksi seluruh komoditas buah yang diusahakan masyarakat di masing-masing kecamatan. Artinya komoditas Jeruk Siam bukan merupakan komoditas buah yang mendominasi diusahakan di kecamatan-kecamatan tersebut.
Terdapat empat (4) kecamatan yang sebelumnya telah dijelaskan pada hasil analisis LQ berdasarkan indikator luas lahan menghasilkan rata-rata nilai LQ lebih dari 1 atau masuk kedalam kecamatan basis komoditas Jeruk Siam namun berdasarkan indikator produksi tidak termasuk dalam kecamatan basis Jeruk Siam. Keempat kecamatan tersebut adalah Kecamatan Pesanggaran, Siliragung, Muncar, dan Tegalsari. Empat kecamatan tersebut tidak menjadi kecamatan basis dikarenakan hasil rataan produksi Jeruk Siam di kecamatankecamatan tersebut lebih rendah atau tidak mampu mengimbangi hasil rataan produksi dari seluruh komoditas buah dalam satu wilayah kecamatan.

Berdasarkan analisis LQ indikator penerimaan yang telah dilakukan, diperoleh hasil seperti yang tersaji pada Tabel 4. Hasil analisis LQ berdasarkan indikator penerimaan menunjukkan bahwa terdapat enam (6) kecamatan yang menghasilkan nilai rata-rata LQ>1 atau disebut sebagai kecamatan basis komoditas Jeruk Siam. Keenam kecamatan tersebut adalah Kecamatan Bangorejo, Purwoharjo, Tegaldlimo, Cluring, Gambiran dan Tegalsari.

Berdasarkan konsistensi per tahun, yang secara konsisten menempati posisi sebagai kecamatan basis komoditas Jeruk Siam berdasarkan indikator penerimaan adalah tidak terdapat kecamatan yang secara konsisten selalu menjadi kecamatan basis selama kurun waktu lima tahun tersebut. Kecamatan Tegaldlimo dengan rata-rata LQ tertinggi

Tabel 3. Hasil Analisis LQ Jeruk Siam Berdasarkan Indikator Produksi (kw) di Kabupaten Banyuwangi

\begin{tabular}{llcccccr}
\hline \multirow{2}{*}{ No } & Kecamatan & \multicolumn{7}{c}{ Nilai LQ Indikator Produksi } \\
\cline { 3 - 8 } & & 2013 & 2014 & 2015 & 2016 & 2017 & Rata-rata \\
\hline 1 & Pesanggaran & 0,5974 & 0,3545 & 0,5541 & 0,2791 & 0,0953 & 0,3761 \\
2 & Siliragung & 0,6676 & 0,2433 & 0,0937 & $\mathbf{1 , 3 7 0 9}$ & $\mathbf{1 , 3 9 4 7}$ & 0,7541 \\
3 & Bangorejo & $\mathbf{2 , 1 2 6 3}$ & $\mathbf{1 , 9 7 7 3}$ & $\mathbf{1 , 5 4 9 7}$ & $\mathbf{2 , 0 8 7 4}$ & 0,7451 & $\mathbf{1 , 6 9 7 1}$ \\
4 & Purwoharjo & $\mathbf{3 , 0 6 9 3}$ & $\mathbf{1 , 8 3 7 7}$ & $\mathbf{1 , 1 6 0 3}$ & $\mathbf{1 , 8 7 5 5}$ & 0,8022 & $\mathbf{1 , 7 4 9 0}$ \\
5 & Tegaldlimo & $\mathbf{2 , 5 9 1 0}$ & $\mathbf{1 , 1 6 4 5}$ & 0,8386 & $\mathbf{1 , 9 0 3 2}$ & 2,0406 & $\mathbf{1 , 7 0 7 6}$ \\
6 & Muncar & 0,6436 & 0,1957 & 0 & 0,8676 & $\mathbf{1 , 3 3 8 2}$ & 0,6090 \\
7 & Cluring & $\mathbf{1 , 4 8 7 1}$ & 0,9755 & 0,4648 & $\mathbf{2 , 0 5 5 3}$ & $\mathbf{2 , 0 2 8 8}$ & $\mathbf{1 , 4 0 2 3}$ \\
8 & Gambiran & $\mathbf{1 , 2 0 8 9}$ & 0,7387 & $\mathbf{1 , 2 0 4 6}$ & $\mathbf{2 , 0 0 2 3}$ & $\mathbf{1 , 8 3 0 7}$ & $\mathbf{1 , 3 9 7 0}$ \\
9 & Tegalsari & $\mathbf{1 , 4 2 2 7}$ & 0,7119 & 0 & $\mathbf{1 , 5 7 2 3}$ & $\mathbf{1 , 2 5 8 7}$ & 0,9931 \\
\hline Sunyyyyyy
\end{tabular}

Sumber: Data Sekunder Diolah (2018) 
sebesar 1,57 tidak menjadi kecamatan konsisten karena pada tahun 2015 menghasilkan nilai LQ kurang dari 1 (LQ<1) atau tidak menjadi kecamatan basis Jeruk Siam. Kecamatan Bangorejo dengan rata-rata LQ tertinggi kedua sebesar 1,38 tidak menjadi kecamatan konsisten karena pada tahun 2017 menjadi kecamatan non basis. Kecamatan Purwoharjo dengan rata-rata LQ tertinggi ketiga sebesar 1,37 tidak menjadi kecamatan konsisten karena pada tahun 2015 dan 2017 menjadi kecamatan non basis. Kecamatan Cluring dengan rata-rata LQ tertinggi keempat sebesar 1,35 tidak menjadi kecamatan konsisten karena pada tahun 2013 dan 2014 menjadi kecamatan non basis. Kecamatan Gambiran dengan rata-rata LQ tertinggi kelima sebesar 1,31 tidak menjadi kecamatan konsisten karena pada tahun 2014 menjadi kecamatan non basis. Kecamatan Tegalsari dengan rata-rata $L Q$ tertinggi keenam atau ratarata LQ terendah sebesar 1,11 tidak menjadi kecamatan konsisten karena pada tahun 2014 dan 2015 menjadi kecamatan non basis. Kecamatan non basis Jeruk Siam berdasarkan indikator penerimaan dapat diartikan bahwa Jeruk Siam bukan merupakan sumber penerimaan terbesar bagi kecamatan-kecamatan tersebut.

Rangkuman kecamatan yang menjadi basis Jeruk Siam berdasarkan rata-rata nilai LQ dalam tiga indikator berbeda yaitu luas lahan, produksi, dan penerimaan tersaji pada Tabel 5 .

Berdasarkan Tabel 5. diketahui bahwa dalam tiga indikator berbeda terdapat jumlah yang berbeda pula yang menjadi kecamatan basis Jeruk Siam di Kabupaten Banyuwangi.

Tabel 4. Hasil Analisis LQ Jeruk Siam Berdasarkan Indikator Penerimaan (Rp) di Kabupaten Banyuwangi

\begin{tabular}{llllrrrr}
\hline & & \multicolumn{5}{c}{ Nilai LQ Indikator Penerimaan } \\
\cline { 3 - 8 } & Kecamatan & 2013 & 2014 & 2015 & 2016 & 2017 & Rata-rata \\
\hline 1 & Pesanggaran & 0,7134 & 0,4932 & 0,5577 & 0,3720 & 0,0717 & 0,4416 \\
2 & Siliragung & 0,7596 & 0,2715 & 0,1031 & 0,8121 & $\mathbf{1 , 5 1 3 8}$ & 0,6920 \\
3 & Bangorejo & $\mathbf{1 , 8 8 2 0}$ & $\mathbf{1 , 5 8 8 8}$ & $\mathbf{1 , 3 5 1 9}$ & $\mathbf{1 , 5 4 2 6}$ & 0,5463 & $\mathbf{1 , 3 8 2 3}$ \\
4 & Purwoharjo & $\mathbf{2 , 2 6 2 0}$ & $\mathbf{1 , 4 3 7 1}$ & 0,9520 & $\mathbf{1 , 4 8 7 9}$ & 0,7517 & $\mathbf{1 , 3 7 8 1}$ \\
5 & Tegaldlimo & $\mathbf{2 , 0 7 8 7}$ & $\mathbf{1 , 0 8 9 9}$ & 0,9809 & $\mathbf{1 , 3 7 8 0}$ & $\mathbf{2 , 3 1 3 2}$ & $\mathbf{1 , 5 6 8 1}$ \\
6 & Muncar & 0,6915 & 0,2653 & 0 & 0,8598 & $\mathbf{1 , 9 6 5 9}$ & 0,7565 \\
7 & Cluring & $\mathbf{1 , 4 8 8 0}$ & 0,9783 & 0,5780 & $\mathbf{1 , 5 4 0 4}$ & $\mathbf{2 , 1 8 0 3}$ & $\mathbf{1 , 3 5 3 0}$ \\
8 & Gambiran & $\mathbf{1 , 1 7 5 6}$ & 0,7124 & $\mathbf{1 , 1 0 3 6}$ & $\mathbf{1 , 5 0 4 7}$ & $\mathbf{2 , 0 6 1 1}$ & $\mathbf{1 , 3 1 1 5}$ \\
9 & Tegalsari & $\mathbf{1 , 5 8 9 4}$ & 0,9108 & 0 & $\mathbf{1 , 3 1 5 2}$ & $\mathbf{1 , 7 1 5 7}$ & $\mathbf{1 , 1 0 6 2}$ \\
\hline
\end{tabular}

Sumber: Data Sekunder Diolah (2018)

Tabel 5. Kecamatan Basis Jeruk Siam di Kabupaten Banyuwangi Indikator Luas Lahan (ha), Produksi (kw) dan Penerimaan (rp)

\begin{tabular}{|c|c|c|c|}
\hline \multirow{2}{*}{ No. } & \multicolumn{3}{|c|}{ Indikator } \\
\hline & Luas Lahan & Produksi & Penerimaan \\
\hline 1. & Purwoharjo & Purwoharjo & Tegaldlimo \\
\hline 2. & Cluring & Tegaldlimo & Bangorejo \\
\hline 3. & Tegaldlimo & Bangorejo & Purwoharjo \\
\hline 4. & Tegalsari & Cluring & Cluring \\
\hline 5. & Bangorejo & Gambiran & Gambiran \\
\hline 6. & Gambiran & & Tegalsari \\
\hline 7. & Siliragung & & \\
\hline 8. & Muncar & & \\
\hline 9. & Pesanggaran & & \\
\hline
\end{tabular}


Rizqa N., Soetriono, Anik S.: Analisis Perwilayahan dan Kontribusi ...

Tabel 6. Hasil Analisis Lokalisasi Jeruk Siam Berdasarkan Indikator Luas Lahan, Produksi dan Penerimaan Tahun 2013-2017 di Kabupaten Banyuwangi

\begin{tabular}{llrrr}
\hline \multirow{2}{*}{ No } & Kecamatan & \multicolumn{3}{c}{ Rata-rata Koefisien Lokalisasi Tahun 2013-2017 } \\
\cline { 3 - 5 } & & Luas Lahan & Produksi & Penerimaan \\
\hline 1 & Pesanggaran & 0,0162 & $-0,0296$ & $-0,0106$ \\
2 & Siliragung & 0,0342 & $-0,0800$ & $-0,0264$ \\
3 & Bangorejo & 0,0926 & 0,0921 & 0,1916 \\
4 & Purwoharjo & 0,1030 & 0,0448 & 0,0484 \\
5 & Tegaldlimo & 0,0909 & 0,0830 & 0,1079 \\
6 & Muncar & 0,0162 & $-0,0203$ & 0,0013 \\
7 & Cluring & 0,0616 & 0,0385 & 0,0595 \\
8 & Gambiran & 0,0288 & 0,0185 & 0,0274 \\
9 & Tegalsari & 0,0401 & 0,0051 & 0,0096 \\
\hline
\end{tabular}

Sumber: Data Sekunder Diolah (2018).

Berdasarkan rata-rata nilai LQ tahun 2013 sampai 2017 yang secara konsisten selalu menjadi kecamatan basis Jeruk Siam pada 3 indikator yang berbeda adalah Kecamatan Bangorejo, Kecamatan Purwoharjo, Kecamatan Tegaldlimo, Kecamatan Cluring, dan Kecamatan Gambiran. Artinya bahwa kecamatan-kecamatan basis tersebut merupakan wilayah yang relatif lebih berpotensi dilakukan pengembangan daripada kecamatan basis yang nonkonsisten.

\section{Karakteristik Penyebaran}

Berdasarkan analisis lokalisasi indikator luas lahan, produksi, dan penerimaan yang telah dilakukan, dperoleh hasil yang tersaji terlihat pada Tabel 6.

Hasil analisis lokalisasi berdasarkan indikator luas lahan, produksi dan penerimaan pada Tabel 5. menunjukkan bahwa dari tahun 2013 sampai 2017 kecamatan-kecamatan yang menjadi wilayah basis komoditas Jeruk Siam berdasarkan tiga indikator tersebut menghasilkan angka koefisien lokalisasi yang berfluktuatif. Hasil analisis lokalisasi juga menunjukkan bahwa rata-rata koefisien lokalisasi pada kecamatan basis komoditas Jeruk Siam bernilai positif kurang dari satu ( $\alpha$ $(+)<1)$. Hal tersebut berarti bahwa komoditas Jeruk Siam tidak terlokalisasi pada suatu kecamatan tertentu melainkan terlokalisasi kecamatan yang menjadi kecamatan basis komoditas Jeruk Siam. Tersebarnya kegiatan usaha pertanian Jeruk Siam di Kabupaten Banyuwangi dikarenakan kecamatan- kecamatan yang bersangkutan memiliki karakteristik iklim, cuaca, dan topografi yang hampir sama sehingga Jeruk Siam dapat dikembangkan dengan baik di kecamatankecamatan tersebut. Tersebarnya kegiatan usaha pertanian Jeruk Siam dapat pula memberikan keuntungan bagi pelaku usahausaha yang berkaitan dengan komoditas Jeruk Siam karena apabila kebutuhan terhadap Jeruk Siam tidak bisa diperoleh di suatu kecamatan maka masih ada kecamatan-kecamatan lain yang dapat dijadikan rujukan untuk memenuhi kebutuhan akan Jeruk Siam. Hal ini sesuai dengan penelitian yang telah dilakukan Syamsiyah et al. (2016) berdasarkan perhitungan koefisien lokalisasi, diketahui bahwa tidak ada yang mencapai nilai 1 artinya bahwa Kabupaten Cirebon tidak melakukan konsentrasi kegiatan usahatani atau kegiatan usahataninya tidak terkumpul hanya di salah satu kecamatan melainkan tersebar di beberapa kecamatan di Kabupaten Cirebon. Selama kurun waktu tahun 2013 hingga 2017 kegiatan pertanian komoditas Jeruk Siam tidak terlokalisasi atau menyebar.

Berdasarkan analisis spesialisasi indikator luas lahan, produksi, dan penerimaan yang telah dilakukan, diperoleh hasil yang pada Tabel 7.

Hasil analisis spesialisasi bahwa kecamatan basis komoditas Jeruk Siam yang menghasilkan angka koefisien lokalisasi positif kurang dari satu $(\alpha(+)<1)$ juga menghasilkan angka koefisien spesialisasi positif kurang dari satu $(\beta(+)<1)$. Artinya bahwa sejak tahun 2013 
Rizqa N., Soetriono, Anik S.: Analisis Perwilayahan dan Kontribusi ...

Tabel 7. Hasil Analisis Spesialisasi Jeruk Siam Berdasarkan Indikator Luas Lahan, Produksi dan Penerimaan Tahun 2013-2017 di Kabupaten Banyuwangi

\begin{tabular}{llrrr}
\hline \multirow{2}{*}{ No } & Kecamatan & \multicolumn{3}{c}{ Rata-rata Koefisien Spesialisasi Tahun 2013-2017 } \\
\cline { 3 - 5 } & & Luas Lahan & Produksi & Penerimaan \\
\hline 1 & Pesanggaran & 0,0220 & $-0,4115$ & $-0,3057$ \\
2 & Siliragung & 0,1253 & $-0,2592$ & $-0,2189$ \\
3 & Bangorejo & 0,1618 & 0,1756 & 0,2207 \\
4 & Purwoharjo & 0,4436 & 0,1525 & 0,1839 \\
5 & Tegaldlimo & 0,2902 & 0,1402 & 0,2513 \\
6 & Muncar & 0,0503 & $-0,3263$ & $-0,1959$ \\
7 & Cluring & 0,2886 & 0,0238 & 0,1406 \\
8 & Gambiran & 0,1838 & 0,0578 & 0,1471 \\
9 & Tegalsari & 0,1606 & $-0,1797$ & $-0,0125$ \\
\hline
\end{tabular}

Sumber: Data Sekunder Diolah (2018)

sampai tahun 2017 kecamatan basis komoditas Jeruk Siam tidak menspesialisasikan komoditas Jeruk Siam di wilayahnya. Hal tersebut dikarenakan sebagian besar masyarakat atau petani yang melakukan usaha budidaya Jeruk Siam tidak menjadikan Jeruk Siam sebagai tanaman utama yang dibudidayakan di lahan mereka dengan kata lain ada komoditas pertanian tertentu lainnya yang dijadikan sebagai komoditas utama di wilayah mereka. Hal ini sesuai dengan penelitian yang telah dilakukan Syamsiyah, dkk (2016) berdasarkan koefisien spesialisasi tidak dihasilkan nilai yang lebih ataupun sama dengan satu artinya di Kabupaten Cirebon tidak satu kecamatanpun yang melakukan spesialisasi pada kegiatan usahatani tertentu. Selama kurun waktu tahun 2013 sampai dengan 2017 di Kabupaten Banyuwangi tidak satupun kecamatan basis komoditas Jeruk Siam yang menspesialisasikan kegiatan pertaniannya pada komoditas Jeruk Siam saja.

Menurut Pasaribu dan Soetriono (2009) untuk menganalisa perkembangan daerah yang dekat hubungannya dengan penelaahan siklus daerah digunakan analisis Regional Multiplier (RM). Analisis pengganda sederhana seperti ini menggunakan telaah dasar perekonomian daerah yang membedakan antara sektor basis dengan sektor non basis. Analisis Regional Multiplier (RM) menunjukkan besarnya angka pengganda atau efek perambatan dari suatu kegiatan budidaya komoditas Jeruk Siam pada suatu wilayah terhadap kegiatan budidaya komoditas Jeruk Siam di wilayah basis.
Besaran angka dampak pengganda (multiplier effect) berdasarkan analisis Regional Multiplier (RM) kegiatan budidaya Jeruk Siam di Kabupaten Banyuwangi berdasarkan indikator luas lahan, produksi dan penerimaan tahun 2013 sampai 2017 tersaji dalam Tabel 8.

Tabel 8. Nilai Regional Multiplier (RM) Komoditas Jeruk Siam di Kabupaten Banyuwangi Berdasarkan Indikator Luas Lahan, Produksi dan Penerimaan Tahun 20132017

\begin{tabular}{cccc}
\hline \multirow{3}{*}{ Tahun } & \multicolumn{3}{c}{ Nilai RM } \\
\cline { 2 - 4 } & $\begin{array}{c}\text { Luas } \\
\text { Lahan }\end{array}$ & Produksi & Penerimaan \\
\hline 2013 & 1,007 & 1,104 & 1,105 \\
2014 & 1,083 & 1,086 & 1,071 \\
2015 & 1,054 & 1,078 & 1,073 \\
2016 & 1,006 & 1,063 & 1,104 \\
2017 & 1,014 & 1,143 & 1,151 \\
\hline
\end{tabular}

Sumber: Data Sekunder Diolah (2018).

Berdasarkan hasil analisis Regional Multiplier (RM) diketahui bahwa RM menunjukkan angka lebih dari satu (RM>1). Artinya usaha budidaya Jeruk Siam di wilayah Kabupaten Banyuwangi memberikan dampak pengganda terhadap usaha budidaya Jeruk Siam di wilayah basis. Nilai RM tertinggi berdasarkan indikator luas lahan terdapat pada tahun 2014 sebesar 1,083, nilai RM tertinggi berdasarkan indikator produksi terdapat pada tahun 2017 sebesar 1,143, nilai RM tertinggi berdasarkan indikator penerimaan terdapat 
Rizqa N., Soetriono, Anik S.: Analisis Perwilayahan dan Kontribusi ...

Tabel 9. Kontribusi Komoditas Jeruk Siam Terhadap Perekonomian Kabupaten Banyuwangi Tahun 20132017

\begin{tabular}{ccccc}
\hline \multirow{2}{*}{ Tahun } & PDRB Jeruk Siam & $\begin{array}{c}\text { PDRB Perekonomian } \\
\text { Kabupaten } \\
\text { Banyuwangi }\end{array}$ & $\begin{array}{c}\text { Kontribusi } \\
\text { Jeruk Siam }\end{array}$ & \multirow{2}{*}{ Keterangan } \\
\cline { 2 - 4 } & (Miliar Rupiah) & (Miliar Rupiah) & $(\%)$ & \\
\hline 2013 & 935,99 & $47.364 .724,70$ & 0,0019 & Rendah \\
2014 & $2.186,15$ & $53.371 .199,30$ & 0,0041 & Rendah \\
2015 & $6.170,71$ & $60.179 .292,90$ & 0,0102 & Rendah \\
2016 & $3.331,77$ & $66.348 .468,12$ & 0,0050 & Rendah \\
2017 & $1.445,59$ & $72.245 .718,94$ & 0,0020 & Rendah \\
\hline
\end{tabular}

Sumber: Data sekunder diolah, 2018

Keterangan: *Rata-rata kontribusi komponen penyusun PDRB Perekonomian Banyuwangi adalah 0,015 \%

pada tahun 2017 sebesar 1,151 yang berarti bahwa setiap kenaikan satu-satuan luas lahan, produksi dan penerimaan Jeruk Siam di Kabupaten Banyuwangi akan meningkatkan luas lahan, produksi dan penerimaan Jeruk Siam di wilayah basis sebesar hasil yang telah diperoleh tersebut. Berdasarkan uraian tersebut dapat dikatakan bahwa usaha pertanian Jeruk Siam di Kabupaten Banyuwangi potensial untuk dilakukan pengembangan.

\section{Kontribusi Komoditas Jeruk Siam terhadap Perekonomian Kabupaten Banyuwangi}

Hasil perhitungan kontribusi komoditas Jeruk Siam terhadap perekonomian Kabupaten Banyuwangi ditampilkan dalam Tabel 9.

Berdasarkan Tabel 9. diketahui bahwa kontribusi Jeruk Siam terhadap PDRB perekonomian Kabupaten Banyuwangi dalam kurun waktu 5 tahun berada pada kriteria rendah. Hal tersebut dikarenakan angka presentase kontribusi Jeruk Siam masih lebih kecil dari rata-rata kontribusi komponen penyusun PDRB perekonomian Kabupaten Banyuwangi $(0,015 \%)$. Kontribusi Jeruk Siam terhadap PDRB perekonomian dari tahun 2013 sampai dengan 2017 berturut-turut adalah 0,$0019 ; 0,0041 ; 0,0102 ; 0,0050$ dan 0,0020 . Rendahnya kontribusi Jeruk Siam disebabkan sumbangan Jeruk Siam masih rendah kepada PDRB subsektor hortikultura Kabupaten Banyuwangi. Hal ini disebabkan ada 48 komoditas hortikultura yang dibudidayakan di Kabupaten Banyuwangi, sehingga nilai penerimaan dari Jeruk Siam memberikan kontribusi yang rendah terhadap perekonomian Kabupaten Banyuwangi. Rendahnya kontribusi Jeruk Siam dimungkinkan pula karena harga Jeruk Siam yang berfluktuatif dari tahun 2013 sampai 2017 bahkan menunjukkan penurunan di dua tahun terakhir dan harga paling rendah berada pada tahun 2017 yaitu hanya sebesar Rp 5500., per kilogram sehingga memberikan peneimaan yang rendah pula untuk Kabupaten Banyuwangi.

\section{KESIMPULAN DAN SARAN}

Berdasarkan hasil-hasil analisis yang telah diperoleh, maka simpulan yang dapat diambil dari penelitian ini adalah Kecamatan penghasil Jeruk Siam di Kabupaten Banyuwangi berdasarkan rata-rata nilai LQ tahun 2013 sampai 2017 yang secara konsisten selalu menjadi kecamatan basis dengan tiga indikator berbeda yaitu luas lahan, produksi dan penerimaan adalah Kecamatan Bangorejo, Kecamatan Purwoharjo, Kecamatan Tegaldlimo, Kecamatan Cluring, dan Kecamatan Gambiran, karakteristik penyebaran komoditas Jeruk Siam di Kabupaten Banyuwangi pada tahun 2013 sampai dengan 2017 tidak terlokalisasi dan tidak terspesialisasi, serta kontribusi komoditas Jeruk Siam terhadap perekonomian Kabupaten Banyuwangi pada tahun 2013 sampai dengan 2017 adalah rendah.

\section{DAFTAR PUSTAKA}

Boekoesoe, Y. 2011. Analisis Perwilayahan Komoditas Mangga di Provinsi Gorontalo. Jurnal Ilmiah Agropolitan, 4 (2), 527-534.

Djarwanto. 2001. Statistik Non Parametrik Bagian 1 Edisi 3. Yogyakarta: BPFEUGM. 
Rizqa N., Soetriono, Anik S.: Analisis Perwilayahan dan Kontribusi ...

Larasati, N. 2011. Faktor-Faktor yang Mempengaruhi Permintaan dan Penawaran Ubi Jalar serta Kontribusinya terhadap Perekonomian Jawa Timur. Skripsi. Jember: Universitas Jember.

Nazir, M. 2005. Metode Penelitian. Jakarta: Ghalia Indonesia.

Mulyono, J. dan Munibah, K. 2016. Pendekatan Location Quotient dan Shift Share Analysis dalam Penentuan Komoditas Unggulan Tanaman Pangan di Kabupaten Bantul. Informatika Pertanian, 25(2), 221-230.

Pasaribu, A.P. dan Soetriono. 2009. Perwilayahan dan Strategi Pengembangan Komoditas Karet (Hevea brasillensis) di Indonesia. J-SEP, 3(3), 114.
Pemkab Banyuwangi. 2016. Rencana Strategis Dinas Pertanian Kabupaten Banyuwangi Tahun 2016-2021. Banyuwangi: Dinas Pertanian Kabupaten Banyuwangi.

Pusat Data dan Informasi Pertanian. 2015. Komoditas Pertanian Hortikultura: Jeruk. Jakarta: Kementerian Pertanian.

Soetriono. 1996. Sektor Basis Kedelai sebagai Pendukung Agroindustri di Kecamatan Ambulu Kabupaten Jember. Agrijurnal, 2(3), 1-13.

Suharyanto, Agustian, A dan Silitonga, P.Y. 2013. Analisis Daya Saing Komoditas Perkebunan Di Kabupaten Kaimana Provinsi Papua Barat. SEPA, 10(1), 148155. 